Another suggestion to explain the discrepancy is that some patients in the present series with mild membranous nephropathy have been included in the minimal change group. This is very unlikely in view of the clinical presentation and course of the 15 patients allocated to the minimal change group. All had highly selective differential protein clearances (Cameron and Blandford, 1966) and normal renal function. Ten of these patients subscquently lost their proteinuria, either spontaneously or as the result of therapy in the associated trial (Sharpstone et al., 1969), and a further four showed great reduction in proteinuria with clinical improvement; only one patient failed to respond to steroids at all.

The possibility remains, however, that there may be geographical variations in the incidence of membranous nephropathy, and a number of clinicians have the impression from experience on either side of the Atlantic that the condition is commoner in the United States than in England.

\section{Sex Incidence}

Even allowing for the difficulty in assessing renal histology just discussed, the sex ratios found in this survey were surprising. In children, a group largely consisting of patients with minimal change histology, a rather constant male : female ratio of $2: 1$ is found (Rothenberg and Heymann, 1957; Arneil, 1961). Most previous series of adult nephrotics have shown either equal sex incidence or a preponderance of males (Heptinstall, 1966), though Pearl et al. (1963) also reported an excess of females in their series, which consisted of 53 adults and children.

\section{Renal Amyloidosis}

Although the trial protocol specifically excluded patients with evidence of multi-system disease, it is of interest that six patients $(10.7 \%$ of total) fulfilling the clinical and biochemical criteria for entty were found on renal biopsy to have amyloidosis. This is in line with the incidence of 11 to $12 \%$ in other series of nephrotic patients (Berman and Schreiner, 1958; Blainey et al., 1960 ; Maxwell et al., 1964) and emphasizes the value of renal biopsy in the nephrotic syndrome in adults. Only one patient had a possible associated condition (mild bronchiectasis), but during the period of the survey biopsy was carried out in a further three patients with amyloidosis, rheumatoid arthritis, and the nephrotic syndrome. This is in keeping with the finding of Brandt et al. (1968) of an equal incidence of the nephrotic syndrome in both primary and secondary amyloidosis.

This was a collaborative study, and the interest and work of large numbers of people made it possible. The consultant physicians of the South-east Metropolitan Region referred their patients to us and to them our thanks are due. Dr. J. S. S. Fairley of the Southeast Metropolitan Regional Hospital Board and his colleagues gave us every facility and a financial grant to help the survey. Dr. F. S. Goldby performed some of the biopsies, and Mr. J. Kaye and Mr. Gabriel Bankole carried out the biochemical estimations. The histological specimens were expertly processed by Mr. D. J. Ware, Mr. J. Osborne, and Mr. R. Francis.

\section{REFERENCES}

Arneil, G. C. (1961). Lancet, 2, 1103.

Berger, J., de Montera, H., and Galle, P. (1961). Archives d'Anatomie Pathologique, 9, 313.

Berman, L. B., and Schreiner, G. E. (1958). American fournal of Medicine, $24,249$.

Blainey, J. D., Brewer, D. B., Hardwicke, J., and Soothill, J. F. (1960). Quarterly fournal of Medicine, 29, 235.

Brandt, K., Cathcart, E. S., and Cohen, A. S. (1968). American Fournal of Medicine, 44, 955 .

Cameron, J. S. (1968). British Medical fournal, 4, 352.

Cameron, J. S. (1968). British Medical fournal, 4, 352.

Heptinstall, R. H. (1966). Pathology of the Kidney, p. 361. London. Hiller, A., McIntosh, J. F., and Van Slyke, D. D. (1927). Fournal of Clinical Investigation, 4, 235.

Kark, R. M., and Muehrcke, R. C. (1954). Lancet, 1, 1047.

McGovern, V. J. (1964). Australasian Annals of Medicine, 13, 306.

Maxwell, M. H., Adams, D. A., and Goldman, R. (1964). Annals of Internal Medictne, 60, 539.

Ogg, C. S., Cameron, J. S., and White, R. H. R. (1968). Lancet, 2, 78.

Pearl, M. A., Burch, R. R., Carvajal, E., McCracken, B. H., Woody, H. B., and Sternberg, W. H. (1963). Archives of Internal Medicine, $112,716$.

Robson, J. S. (1967). In Renal Disease, 2nd ed., edited by D. A. K. Black, p. 276. Oxford.

Rothenberg, M. B., and Heymann, W. (1957). Pediatrics, 19, 446.

Sharpstone, P., Ogg, C. S., and Cameron, J. S. (1969). British Medical fournal, i, 535 .

\title{
Nephrotic Syndrome Due to Primary Renal Disease in Adults: II. A Controlled Trial of Prednisolone and Azathioprine
}

\author{
P. SHARPSTONE,* M.B., M.R.C.P.; C. S. OGG, † M.D., B.SC., M.R.C.P. ; J. S. CAMERON, $\ddagger$ M.D., B.SC., M.R.C.P.
}

\begin{abstract}
Cummary : A controlled trial in 20 adult patients with $\checkmark$ the nephrotic syndrome due to proliferative glomerulonephritis compared the effects of consecutive eight-week courses of treatment with prednisolone in conventional dosage and a low-dose azathioprine-prednisolone combination. Though the azathioprine regimen avoided serious toxicity and produced a statistically significant improvement in creatinine clearance and urine protein excretion, the results were not significantly better than with prednisolone itself and overall were not of great clinical value. Prolongation of the azathioprine-predniso-
\end{abstract} * Lecturer in Medicine, King's College Hospital Medical School, London
S.E.5.

† Renal Physician, Guy's Hospital, London S.E.1.

₹ Renal Physician and Senior Lecturer, Department of Medicine, Guy's Hospital, London S.E.1. lone treatment to one year was associated with some small improvement in the results.

The effectiveness of prednisolone in the nephrotic syndrome of adults with minimal renal histological abnormality was confirmed by a complete loss of proteinuria within eight weeks in six out of eight patients and substantial reduction in the other two. These two patients subsequently received azathioprine as well but with equivocal results.

\section{Introduction}

The value of corticosteroids in the treatment of adult patients with the nephrotic syndrome is small because this is largely confined to those with mild or minimal lesions of the glomeruli 
(Blainey et al., 1960 ; Nesson et al., 1963 ; Pearl et al., 1963 ; Jensen and Jensen, 1967 ; Cameron, 1968). The demonstration of some benefit from the use of cytotoxic and antimetabolite drugs in some patients with corticosteroid-resistant disease (White et al., 1966 ; Adams et al., 1967 ; Michael et al., 1967 ) is thus of great interest. The results of these investigations, though encouraging, were variable, the patients were selected according to varying criteria, and different drug regimens were used. Evaluation of the significance of these findings is difficult and the need for a controlled trial with statistical assessment of the results is clear (British Medical fournal, 1966 ; New England fournal of Medicine, 1967).

The present trial was designed to compare the short-term effect of prednisolone given in conventional dosage with that of prednisolone in lower dosage in combination with azathioprine in adult patients with the nephrotic syndrome due to primary renal disease. Each patient received both treatments and thus acted as his own control. Relatively low dosage of azathioprine was used to minimize toxic effects and to test the possibility of obtaining a useful result with a regimen suitable for outpatient use. Azathioprine was chosen for initial trial because of greater previous experience of its use in glomerulonephritis and in the field of transplantation. Prednisolone in moderate dosage was given concurrently because of the possibility of a synergistic action with azathioprine (Michael et al., 1967) and also for its possible protective effect against leucopenia (John, 1966).

\section{Design of the Trial}

For the purpose of this trial the nephrotic syndrome was defined as proteinuria greater than $3 \mathrm{~g} . / 24$ hours, serum albumin less than $3 \mathrm{~g} . / 100 \mathrm{ml}$., and oedema at the time of starting treatment or within two weeks of this. The other criteria for entering were: age over 14 years, absence of clinical or laboratory evidence of any multisystem disease with which the nephrotic syndrome may be associated (except HenochSchönlein syndrome), and the absence of previous treatment with corticosteroid or other immunosuppressive drug.

Thirty-four patients satisfied the criteria for the trial and comprised the first 32 consecutive patients seen in a survey of the nephrotic syndrome in adults in the South-east Metropolitan Region of England (Sharpstone et al., 1969), plus two patients referred from outside this region. In three cases permission for entry to the trial was withheld by the referring physician and two patients did not receive the scheduled drug dosage. These five patients (all of whom had minimal change renal histology) are not considered further.

\section{Treatment}

Each patient was given consecutive eight-week courses of treatment with (1) prednisolone in conventional dosage and (2) lower dose of prednisolone in conjunction with azathioprine. Regimen 1 comprised prednisolone $60 \mathrm{mg}$. daily for three days, $45 \mathrm{mg}$. daily for seven days, then $20 \mathrm{mg}$. daily to eight weeks; and regimen 2 comprised prednisolone $20 \mathrm{mg}$. daily plus azathioprine $150 \mathrm{mg}$. daily for eight weeks. The order of treatments was randomized for patients allocated after renal biopsy as proliferative glomerulonephritis or membranous nephropathy. Patients with minimal change lesions all received prednisolone in the first instance. Patients whose urine became protein-free-that is, negative or trace to Albustix on three consecutive days-at any stage left the trial ("cure"). Ifter completion of 16 weeks' treatment patients with persisting proteinuria were treated for a further eight months with regimen 3, azathioprine $150 \mathrm{mg}$. daily in combination with a slightly lower dose of prednisolone-15 mg. daily.

The patients remained under the care of the referring physiciars at their own hospitals, and no attempt was made to standardize other therapeutic measures such as duration of stay in hospital, diet, diuretics, or antihypertensive drugs.

\section{Assessment}

New patients were visited by one of us at the referring hospital, a note was made of the history and initial clinical and laboratory findings, and aliquots of three measured 24-hour urine collections and a plasma sample were taken. Renal biopsy was carried out by the technique of Kark and Muehrcke (1954). Classification of the renal histology was as described in the previous paper (Sharpstone et al., 1969), and on notification of the result of this to the referring physician the allocated treatment regimen was started. At the end of each of the three treatment periods further plasma samples and aliquots of three 24-hour urine collections were requested. Chemical estimations were carried out centrally and results obtained for 24hour creatinine clearance, urea clearance, and protein excretion, all averaged over three days. In addition plasma $\beta_{, \mathrm{c}}$-globulin concentration and the selectivity of differential urine protein clearances were measured on the initial samples. A note of the results of clinical assessment, serum proteins, urine protein excretion, blood urea, and white blood count was made at twoweekly intervals for the first 16 weeks and two-monthly thereafter by the referring physician on a form which was returned at the end of the trial.

\section{Chemical Methods}

Creatinine was measured as dialysable Jaffé-positive chromogens by the standard AutoAnalyzer technique. Urea was measured by the diacetyl monoxime method by means of an AutoAnalyzer. Urine proteins were measured by the biuret method of Hiller et al. (1927). Serum albumin was measured on an AutoAnalyzer by the biuret method. $C^{\prime} 3$ component of complement $\left(\beta_{1 \mathrm{C}}\right.$-globulin) was measured as $\beta_{1 \mathrm{~A}}$-globulin in aged sera or plasmas, the method of Ogg et al. (1968) being used. Differential protein clearances were measured by the method of Cameron and Blandford (1966) and expressed as the ratio urinary $\mathrm{C}_{\mathrm{Ig}} / \mathrm{C}$ transferrin.

\section{Results}

Twenty-nine patients entered the trial; 20 had proliferative glomerulonephritis of varying degrees of severity, eight had no or minimal histological abnormality, and one had membranous nephropathy. The renal biopsy findings and initial features for the first two groups are given in Tables I and II, while the single patient with membranous nephropathy is not considered further.

\section{Proliferative Glomerulonephritis : Results after 8 and 16 Weeks}

Deaths.-Three patients died within 16 weeks of starting treatment. Case 4 entered the trial with chronic renal failure (blood urea $246 \mathrm{mg} . / 100 \mathrm{ml}$., creatinine clearance $6 \mathrm{ml} . / \mathrm{min}$.) and died of uraemia two weeks later while on prednisolone. Case 6 , known previously to have had proteinuria, developed the nephrotic syndrome after partial gastrectomy for duodenal ulcer; rapidly reaccumulating ascites required peritoneal drainage, and he died while on prednisolone, two weeks after admission, from hypovolaemia in spite of massive infusions of plasma expanders. Case 8 initially had severely impaired renal function and hypertension. Rapid deterioration occurred during eight weeks on the azathioprine regimen, and she died after six weeks on prednisolone. 
TABLE I.-Initial Clinical and Laboratory Findings in 20 Patients with Proliferative Glomerulonephritis

\begin{tabular}{|c|c|c|c|c|c|c|c|c|c|}
\hline $\begin{array}{l}\text { Case } \\
\text { No. }\end{array}$ & Sex & Age & Renal Histology & $\underset{\text { (mm. }}{\text { B.P. }}$ & $\begin{array}{l}\text { Selectivity of } \\
\text { Proteinuria } \\
\text { (C } C_{12 G / C} \\
\text { Transferrin) }\end{array}$ & $\begin{array}{c}\text { Plasma C'3 } \\
\text { (mg./100 ml.) }\end{array}$ & $\begin{array}{c}\text { Plasma } \\
\text { Albumin } \\
\text { (g. } / 100 \mathrm{ml} .)\end{array}$ & $\begin{array}{l}\text { Blood Urea } \\
\text { (mg./100 ml.) }\end{array}$ & $\begin{array}{l}\text { Plasma } \\
\text { Cholesterol } \\
\text { (mg. } / 100 \mathrm{ml} .)\end{array}$ \\
\hline $\begin{array}{l}1 \\
2 \\
3 \\
4 \\
5 \\
6\end{array}$ & $\begin{array}{l}\mathrm{F} \\
\mathbf{M} \\
M \\
M \\
M \\
M\end{array}$ & $\begin{array}{l}40 \\
64 \\
46 \\
41 \\
55 \\
47\end{array}$ & $\begin{array}{l}\text { P.G.N., some crescents } \\
\text { P.G.N., mild } \\
\text { P.G.N., severe } \\
\text { P.G.N. with sclerosis } \\
\text { P.G.N., cute exudative } \\
\text { P.G.N., severe; scarring and capillary wall }\end{array}$ & $\begin{array}{l}170 / 100 \\
200 / 110 \\
150 / 100 \\
205 / 120 \\
140 / 80\end{array}$ & $\begin{array}{l}0.73 \\
0.02 \\
0 \cdot 68 \\
0.76 \\
0 \cdot 16\end{array}$ & $\begin{array}{r}180 \\
210 \\
194 \\
98\end{array}$ & $\begin{array}{l}2.8 \\
2.1 \\
1.8 \\
2.5 \\
2.3\end{array}$ & $\begin{array}{r}90 \\
30 \\
55 \\
246 \\
45\end{array}$ & $\begin{array}{l}160 \\
420 \\
310 \\
225\end{array}$ \\
\hline $\begin{array}{l}7 \\
8 \\
9 * \\
10 \\
11 \\
12 \\
13 \\
14 \\
15 \\
16 \\
17\end{array}$ & 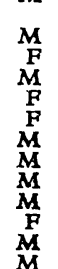 & $\begin{array}{l}15 \\
58 \\
56 \\
48 \\
30 \\
64 \\
21 \\
54 \\
21 \\
45 \\
20 \\
69\end{array}$ & $\begin{array}{l}\text { thickening } \\
\text { P.G.N., acute exudative, resolving } \\
\text { P.G.N., severe } \\
\text { P.G.N., some crescents } \\
\text { P.G.N., severe with glomerulosclerosis } \\
\text { P.G.N., mild } \\
\text { P.G.N., severe with glomerulosclerosis } \\
\text { P.G.N. } \\
\text { P.G.N., severe } \\
\text { P.G.N., mild }\end{array}$ & $\begin{array}{l}150 / 100 \\
160 / 105 \\
210 / 130 \\
130 / 80 \\
200 / 120 \\
150 / 120 \\
180 / 110 \\
190 / 120 \\
140 / 90 \\
130 / 90 \\
140 / 80 \\
140 / 90\end{array}$ & $\begin{array}{l}0.28 \\
0.26 \\
0.69 \\
0.40 \\
0.78 \\
0.51 \\
0.14 \\
0.28 \\
0.19 \\
0.31 \\
0.31 \\
0.23\end{array}$ & $\begin{array}{r}114 \\
13 \\
140 \\
105 \\
72 \\
180 \\
180 \\
180 \\
150 \\
112 \\
125\end{array}$ & $\begin{array}{l}1.1 \\
1.8 \\
2.0 \\
2.0 \\
2.9 \\
2.1 \\
1.9 \\
2.0 \\
2.4 \\
1.8 \\
2.5 \\
1.1\end{array}$ & $\begin{array}{r}188 \\
45 \\
92 \\
43 \\
55 \\
31 \\
38 \\
30 \\
33 \\
32 \\
28 \\
73\end{array}$ & $\begin{array}{l}500 \\
310 \\
300 \\
320 \\
250 \\
275 \\
560 \\
355 \\
430 \\
600 \\
325\end{array}$ \\
\hline $\begin{array}{l}19 \\
20\end{array}$ & $\underset{\mathbf{M}}{\mathbf{F}}$ & $\begin{array}{l}68 \\
65\end{array}$ & $\begin{array}{l}\text { Proliferative) } \\
\text { p.G.N. } \\
\text { P.G.N., mild }\end{array}$ & $\begin{array}{l}190 / 90 \\
190 / 90 \\
180 / 100\end{array}$ & $\begin{array}{l}0.37 \\
0.43 \\
0.07\end{array}$ & $\begin{array}{l}115 \\
140 \\
115\end{array}$ & $\begin{array}{l}2.3 \\
2.8 \\
2.5\end{array}$ & $\begin{array}{l}30 \\
24 \\
44\end{array}$ & $\begin{array}{l}362 \\
355 \\
310\end{array}$ \\
\hline
\end{tabular}

P.G.N. = Proliferative glomerulonephritis.

* Nephrotic syndrome associated with anaphylactoid purpura.

Toxic Withdrawal.-Case 14 was withdrawn from the trial after 13 weeks because of vomiting produced by azathioprine. There had been no objective evidence of improvement in his renal function on either of the regimens. No other significant side-effect of treatment occurred during this part of the trial. In most patients the white blood count remained within normal limits throughout, and in no case did the white blood count fall to below $5,000 / \mathrm{cu}$. $\mathrm{mm}$.

TABLE II.-Initial Clinical and Laboratory Findings in Eight Patients with No or Minimal Histological Abnormality

\begin{tabular}{|c|c|c|c|c|c|c|c|c|}
\hline $\begin{array}{l}\text { Case } \\
\text { No. }\end{array}$ & Sex & Age & $\underset{(\mathrm{mm} . \mathbf{H g})}{\text { B.P. }}$ & $\begin{array}{c}\text { Selectivity } \\
\text { of } \\
\text { Proteinuria } \\
\text { (CI2G/C } \\
\text { Trans- } \\
\text { ferrin) }\end{array}$ & $\begin{array}{c}\text { Plasma } \\
\text { C'3 } \\
\text { (mg.l } \\
100 \mathrm{ml} .)\end{array}$ & $\begin{array}{c}\text { Plasma } \\
\text { Albumin } \\
\text { (g. } / \\
100 \mathrm{ml} .)\end{array}$ & $\begin{array}{c}\text { Blood } \\
\text { Urea } \\
\text { (mg.l } \\
100 \mathrm{ml} .)\end{array}$ & $\begin{array}{c}\text { Plasma } \\
\text { Choles- } \\
\text { terol } \\
\text { (mg./ } \\
100 \mathrm{ml} .)\end{array}$ \\
\hline $\begin{array}{l}21 \\
22 \\
23 \\
24 \\
25 \\
26 \\
27 \\
28\end{array}$ & $\begin{array}{c}M \\
M \\
\text { F } \\
\text { F } \\
\text { M } \\
\text { F } \\
\text { F } \\
\text { F }\end{array}$ & $\begin{array}{l}36 \\
43 \\
60 \\
15 \\
51 \\
37 \\
37 \\
44\end{array}$ & $\begin{array}{l}140 / 90 \\
135 / 100 \\
160 / 90 \\
150 / 90 \\
120 / 70 \\
115 / 85 \\
115 / 85 \\
120 / 80\end{array}$ & $\begin{array}{l}0.55 \\
0.09 \\
0.11 \\
0.02 \\
0.15 \\
0.21 \\
0.13\end{array}$ & $\begin{array}{l}180 \\
140 \\
190 \\
110 \\
212 \\
140 \\
180\end{array}$ & $\begin{array}{l}1 \cdot 2 \\
2 \cdot 1 \\
2 \cdot 0 \\
1.7 \\
1.2 \\
2.4 \\
2.5 \\
1.0\end{array}$ & $\begin{array}{l}54 \\
55 \\
54 \\
21 \\
25 \\
32 \\
23 \\
36\end{array}$ & $\begin{array}{l}540 \\
605 \\
420 \\
240 \\
550 \\
490 \\
540 \\
970\end{array}$ \\
\hline
\end{tabular}

"Cures."-The urine of two patients became protein free. Case 5 had the histological picture of acute diffuse exudative glomerulonephritis (though oedema had been first noticed six months previously) and lost his proteinuria within six weeks of entry to the trial while on the azathioprine regimen. Case 20, with a mild proliferative lesion, also started treatment with the azathioprine combination and lost his proteinuria within six weeks.

The results of investigations at the start and finish of each of the treatment periods are given in Table III. Of the 14 patients who completed both courses of treatment equal numbers received steroid alone as the first treatment as received the combined regimen first. The mean results before treatment and the mean changes after eight weeks on each of the treatment regimens are given in Table IV for the 14 completed courses of prednisolone and for the 16 completed courses of the combined treatment.

The mean results of each investigation at the start of each of the treatment periods did not differ significantly. A significant reduction in proteinuria occurred during both treatments, with a greater fall during azathioprine, but the difference between the effects of the two treatments was not statistically significant. Only azathioprine in combination with predni'solone resulted in a significant increase in creatinine clearance, which did, however, increase to a lesser extent with the steroid regimen. When the two treatments were compared no significant difference was found between them. Exclusion from analysis of the two patients whose urine became free from protein resulted in loss of significance $(P>0.05)$ of both the mean reduction of proteinuria $(2 \cdot 86 \mathrm{~g} . / 24$ hours $)$ and the increase in creatinine clearance $(15.3 \mathrm{ml} . / \mathrm{min}$.) with the azathioprine-prednisolone combination. The mean urea clearances of the 10 patients for whom this investigation was available did not change significantly with either treatment.

TABLE III.-Results of Initial Renal Function Tests and Results after 8 Weeks, 16 Weeks', and 1 Year's Treatment in 20 Patients with Proliferative Glomerulonephritis

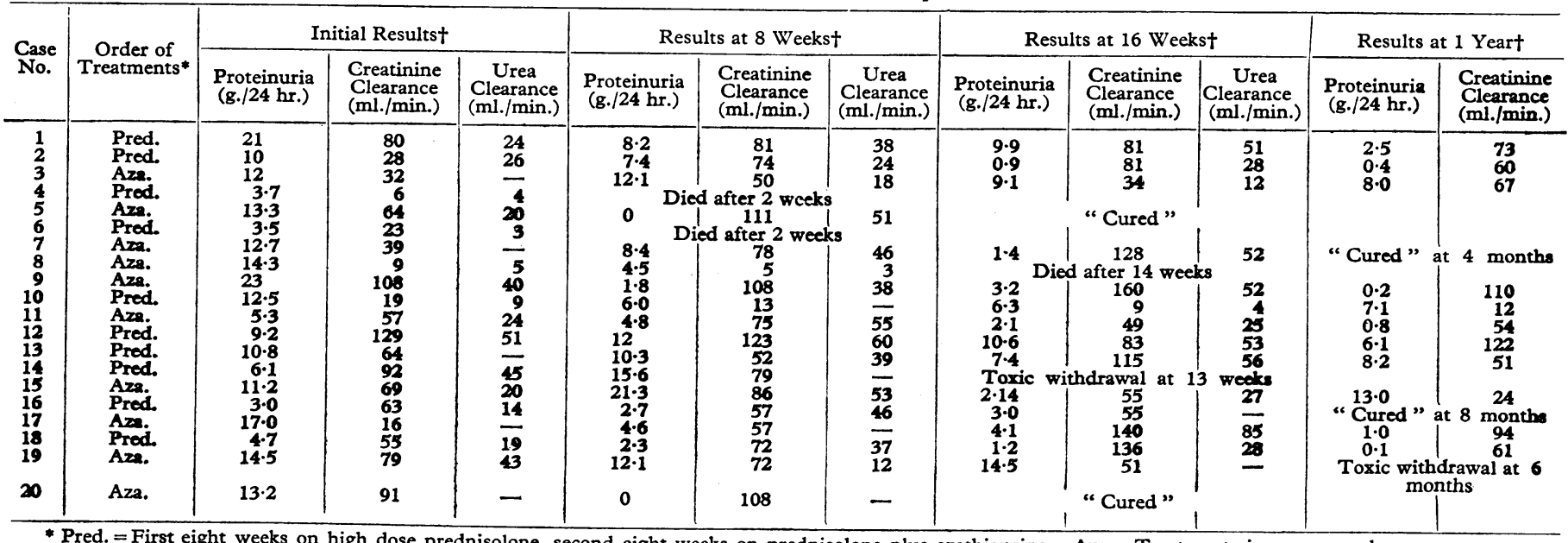

* Pred. $=$ First eight weeks on high dose pred
+ Mean of three 24-hour urine collections. 
TABLE IV._Mean Pretreatment Results and Mean Changes after Two Treatment Regimens in Patients with Proliferative Glomerulonephritis

\begin{tabular}{|c|c|c|c|c|c|c|c|}
\hline & & \multicolumn{2}{|c|}{ High-dose Prednisolone } & \multicolumn{2}{|c|}{ Prednisolone + Azathioprine } & \multirow{2}{*}{\multicolumn{2}{|c|}{ Difference between the Two Regimens }} \\
\hline & & No. of Cases & Mean \pm S.E. & No. of Cases & Mean \pm S.E. & & \\
\hline $\begin{array}{l}\text { Creatinine clearance } \\
\text { (ml./min.) }\end{array}$ & $\begin{array}{l}\text { Before treatment } \\
\text { Change on treatment } \\
\mathbf{P}\end{array}$ & 14 & $\begin{array}{l}68 \cdot 9 \pm 7 \cdot 6 \\
+8 \cdot 9 \pm 9 \cdot 3 \\
\text { N.S. }\end{array}$ & 16 & $\begin{array}{c}64 \cdot 2 \pm 7.5 \\
+17 \cdot 4 \pm 7.0 \\
0.05>P>0.02\end{array}$ & $\begin{array}{l}4 \cdot 7 \\
8 \cdot 5\end{array}$ & N.S. \\
\hline $\begin{array}{l}\text { Urine protein excretion } \\
(\mathrm{g} . / 24 \mathrm{hr} .)\end{array}$ & $\begin{array}{l}\text { Before treatment } \\
\text { Change on treatment } \\
\mathbf{P}\end{array}$ & 14 & $\begin{array}{c}9.7 \pm 1.60 \\
-2.26 \pm 1.12 \\
0.05>P>0.02\end{array}$ & 16 & $\begin{array}{c}10.7 \pm 1.34 \\
-4 \cdot 17 \pm 1.89 \\
0.05>P>0.02 \\
\end{array}$ & $\begin{array}{l}1.0 \\
1.91\end{array}$ & $\begin{array}{l}\text { N.S. } \\
\text { N.S. }\end{array}$ \\
\hline $\begin{array}{l}\text { Urea clearance } \\
\text { (ml./min.) }\end{array}$ & $\begin{array}{l}\text { Before treatment } \\
\text { Change on treatment } \\
\mathbf{P}\end{array}$ & 10 & $\begin{array}{l}34 \cdot 4 \pm 5 \cdot 0 \\
+2 \cdot 9 \pm 6 \cdot 1 \\
\text { N.S. }\end{array}$ & 10 & $\begin{array}{l}34 \cdot 5 \pm 4 \cdot 0 \\
+8 \cdot 0 \pm 6 \cdot 6 \\
\text { N.S. }\end{array}$ & $\begin{array}{l}0 \cdot 1 \\
5 \cdot 1\end{array}$ & $\begin{array}{l}\text { N.S. } \\
\text { N.S. }\end{array}$ \\
\hline
\end{tabular}

S.E. = Standard error.

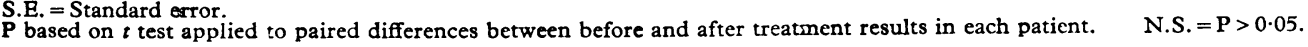

\section{Results at One Year}

The results after a further eight months' treatment with azathioprine and prednisolone are shown in Table III. By this time two further patients (Cases 7 and 16) had lost their proteinuria. Case 19 was withdrawn from the trial at six months because of cellulitis of the legs and buccal ulceration, but her white blood count at this time was 20,000/cu. mm. and probably these complications were the result of her disease rather than the treatment.

For the remaining 11 patients the mean paired change in creatinine clearance between 16 weeks and one year was -15.9 $\pm 10.8 \mathrm{ml} . / \mathrm{min}$. $(P>0.1)$ and the change in proteinuria was $-2.6 \pm 0.95$ g. $/ 24$ hours $(0.05>P>0.02)$.

\section{Minimal Change Histology}

The urine of six of the eight patients in this group became free from protein within eight weeks of starting on prednisolone, and in the other two cases there was a definite reduction (Table V). These two patients subsequently received azothioprine in addition, with a decrease in proteinuria in one and an increase in the other. Case 1 subsequently lost his proteinuria on continued treatment with the two drugs, while in Case 3 heavy proteinuria persisted. Three of the remaining patients remained in remission to one year without further treatment, while the other three relapsed after stopping prednisolone and required further steroid treatment.

TABLB V.-Results of Initial Renal Function Tests and Results at Eight Weeks, 16 Weeks, and One Year in the Eight Patients with No or Minimal Histological Abnormatity

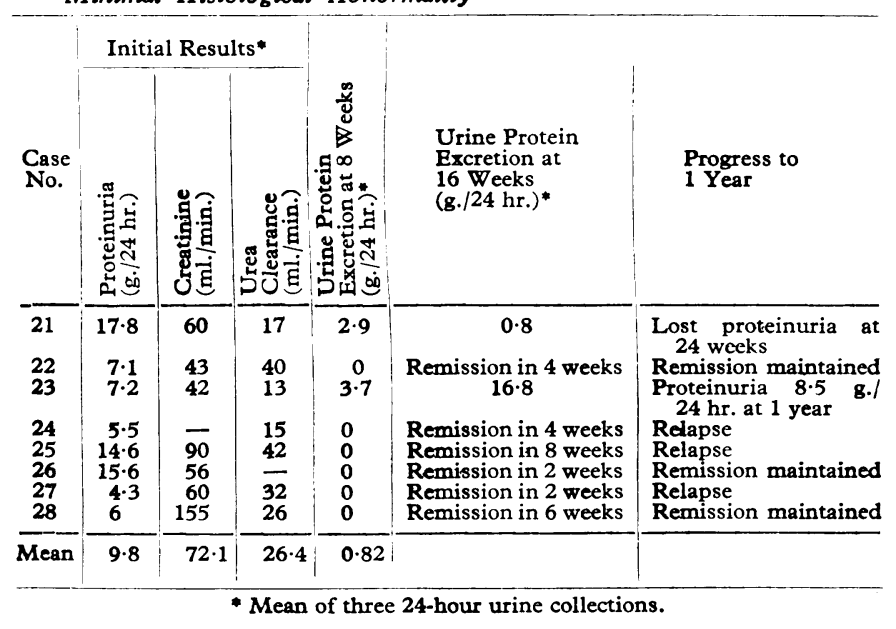

\section{Discussion}

\section{Proliferative Glomerulonephritis}

Evidence had previously been obtained in small numbers of patients of the ability of azathioprine, cyclophosphamide, and related drugs to influence the course of some patients with the nephrotic syndrome due to proliferative glomerulonephritis. The results of earlier investigations were summarized by White et al. (1966), who themselves found a favourable response to azathioprine or cyclophosphamide, usually in combination with prednisolone, in 12 out of 18 patients, most of whom were children. Adams et al. (1967) and Michael et al. (1967), however, did not produce improvement with azathioprine and prednisolone in a total of six adult patients, though in some patients with glomerulonephritis unaccompanied by the nephrotic syndrome both groups obtained more encouraging results.

The dosage of immunosuppressive drugs used in all these studies was such as to cause serious toxic effects such as anaemia, leucopenia, gastrointestinal disturbances, and alopecia in a high proportion of cases. The dose of azathioprine used in the present trial succeeded in avoiding these consequences in all but one patient. We have, however, seen serious leucopenia in another patient, not included in this trial, who had severely impaired renal function and was treated similarly. Another possible longer-term side-effect of the immunosuppressive treatment was the development of lymphosarcoma in Case 2. He died of heart failure due to endomyocardial fibrosis of the left ventricle eight months after finishing one year of treatment in the trial. Dyspnoea and cardiac enlargement antedated the start of prednisolone and azathioprine, suggesting that the cardiac lesion was not a complication of the treatment. Shortly before his death, however, inguinal lymph node enlargement was noted, and necropsy showed lymphosarcoma of inguinal and iliac lymph nodes. Though the development of a lymphoma after immunosuppressive treatment may have been fortuitous in this patient, this association has been noted previously. Reticulum-cell sarcomas have been reported in three patients receiving azathioprine as well as other immunosuppressive drugs after renal transplantation (Doak et al., 1968; Woodruff, 1969), and in the experimental field NZB and NZB/NZW mice have been shown to develop thymic lymphomas after the administration of azathioprine alone (Casey, 1968a, 1968b).

The present findings show a statistically significant mean increase in creatinine clearance and decrease in proteinuria in 16 patients with the nephrotic syndrome due to proliferative glomerulonephritis after eight weeks' treatment with azathioprine $150 \mathrm{mg}$. daily and prednisolone $20 \mathrm{mg}$. daily. With prednisolone by itself in a dose of $60 \mathrm{mg}$. daily reducing to $20 \mathrm{mg}$. daily over eight weeks the urine protein excretion decreased significantly, but the increase in creatinine clearance was not significant. Though the results with the combined regimen were more favourable than with steroid alone, comparison of the two forms of treatment showed that this advantage was not significant. The M.R.C. trial of corticosteroid therapy in the nephrotic syndrome (Rose and Black, 1967) showed that some decrease in the quantity of proteinuria was found in adults with proliferative glomerulonephritis, equally in those who received corticosteroids and those who did not. In this situation of the present trial; where both regimens apparently show an effect and no untreated group is included, 
the assumption must be made that most or all of the improvement is part of the natural bistory of the condition.

Though our findings suggest that azathioprine for eight weeks in the dose used may have some slight favourable influence on the course of the disease, the clinical benefit to the patients was small, most of the patients still falling within our definition of the nephrotic syndrome after treatment. Of the two "cured" patients, one had the histological picture of acute glomerulonephritis and the other a mild glomerular lesion, and in both cases the possibility of a remission occurring with steroid alone or without any treatment cannot be excluded. Investigation of a larger number of patients might improve the statistical significance of the results, but it seems likely that our original hope of producing substantial benefit in the short term with relatively non-toxic doses of azathioprine and prednisolone will not be realized.

The significance of the results of a further 36 weeks' treatment with the combined drugs is limited, since no controls were available for this period. Proteinuria was lost in two further patients and significantly reduced in the others. The mean fall in creatinine clearance during this time was not statistically significant, but possibly deteriorating renal function accounted in part for the diminished proteinuria in the latter patients. Nevertheless, these results do perhaps indicate that in future trials treatment periods of longer than eight weeks' duration should be assessed.

We cannot conclude from this study that immunosuppressive or cytotoxic agents are without value in nephrotics with proliferative glomerulonephritis. Proliferative glomerulonephritis may comprise a variety of different conditions. The possibility remains that the low-dose azathioprine treatment may be of value in some of the patients, such as those with mild lesions. Because of the small numbers in the present trial, further subdivision of the patients was impossible, but this question may be answered by larger collaborative trials such as that currently being sponsored by the Medical Research Council. A second possibility is that larger doses of azathioprine may be effective. Our previous experience (White et al., 1966) of the toxic effects of these higher doses renders this approach too dangerous to be useful. Finally, a third possibility is that another cytotoxic agent, such as cyclophosphamide or chlorambucil, might be effective. It is by no means certain that any of these agents act via their immunosuppressive activity, and their success in this minimal change group, where there is no evidence as yet of any immune disturbance, supports this suggestion. At present wo are investigating the value of cyclophosphamide and chlorambucil in the group of patients discussed in this paper.

\section{Minimal Change Lesion}

Corticosteroid therapy alone produces remission of proteiruria in most children with the nephrotic syndrome and normal or minimal change renal histology (White, 1967 ; Cameron, 1968), and similar results have been obtained in the smaller number of adults investigated (Blainey et al., 1960; Nesson et al., 1963 ; Pearl et al., 1963 ; Jensen and Jensen, 1967 ; Cameron, 1968). Our results confirm that the overall poorer response to corticosteroid therapy of the nephrotic syndrome in adults is due to the higher proportion of patients with severe glomerular disease in this age group rather than to any difference in the response to corticosteroids between adults and children who have minimal lesions.
The main problems in the management of these patients are the groups who require unacceptably high doses of steroid for control (steroid resistant) or who relapse frequently between course of treatment (steroid dependent). Cytotoxic drugs have been strikingly successful in children in this situation (White, 1967 ; Lagrue et al., 1967 ; Moncrieff ot al., 1969 ; Soothill et al., 1969). In most instances cyclophosphamide or chlorambucil was used. In adults little information is available for any cytotoxic agent in this group. Whereas Adams et al. (1967) produced remission in the two patients they treated with azathioprine and prednisolone, Michael ot al. (1967) had a favourable response in only one out of three such patients. In the two patients in the present trial who failed to lose proteinuria on prednisolone the addition of azathioprine for eight weeks was associated with a reduction in proteinuria in one and an increase in the other.

This was a collaborative study, and the interest and work of large numbers of people made it possible. The consultant physicians of the South-east Metropolitan Region referred their patients to us, and to them our thanks are due. Dr. J. S. S. Fairley, of the South-east Metropolitan Regional Hospital Board, and his colleagues gave us every facility and a financial grant. Dr. F. S. Goldby performed some of the biopsies, and Mr. J. Kaye and Mr. Gabriel Bankole carried out the biochemical estimations. The histological specimens were expertly processed by Mr. D. J. Ware, Mr. J. Osborne, and Mr. R. Francis.

\section{REFBRENCES}

Adams, D. A., Gordon, A., and Marwell, M. H. (1967). Fournal of the American Medical Association, 199, 459.

Blainey, J. D., Brewer, D. B., Hardwicke, J., and Soothill, J. F. (1960) Quarterly fournal of Medicine, 29, 235.

British Medical foumal, 1966, 2, 842.

Cameron, J. S. (1968). British Medical Fournal, 4, 352.

Cameron, J. S., and Blandford, G. (1966). Lances, 2, 242.

Casey, T. P. (1968a). Clinical and Experimental Immunology, 3, 305.

Casey, T. P. (1968b). Blood, 31, 396.

Doak, P. B., Montgomerte, J. Z., North, J. D. K., and Smith, F. (1968) British Medical Yournal, 4, 746.

Miller, A., Mackintosh, J. F., and Van Slyke, D. D. (1927). Yournal of Clinical Investigation, 4, 235.

Jensen, H., and Jensen, B. (1967). Acta Medica Scandinavica, 182, 741. John, T. J. (1966). American Fournal of Diseases of Children, 111, 68. Kart, R. M., and Muehrcke, R. C. (1954). Lancet, 1, 1047.

Lagrue, G., Bariéty, J., Canlorbe, P., Vassai, J., and Milliez, P. (1967). Presse Médicale, 75, 1773.

Michael, A. F., et al. (1967). New England Yournal of Medicine, 276, 817.

Moncrieff, M. W., White, R. H. R., Ogg, C. S., and Cameron, J. S. (1969). British Medical Fournal, 1, 666.

Nesson, H. R., Sproul, L. B., jun., Relman, A. S., and Schwartz, W. B. (1963). Anrals of Internal Medicine, 58, 268.

New England fournal of Medicine, 1967, 276, 868.

Ogg, C. S., Cameron, J. S., and White, R. H. R. (1968). Lancet, 2, 78.

Pearl, M. A., Burch, R. R., Carvajal, E., McCracken, B. H., Woody, H. B., and Sternberg, W. H. (1963). Archives of Internal Medicine, $112,716$.

Rose, G., and Black, D. A. K. (1967). Quarterly Fournal of Medicine, 36, 607 (Abstract).

Sharpstone, P., Ogg, C. S., and Cameron, J. S. (1969). British Medical fournal, 2 ,

Soothill, J. F., McLaine, P. N., Cottom, D. G., and Wolf, O. H. (1969). Nephron (Abstract). In press.

White, R. H. R. (1967). Proceedings of the Royal Society of Medicine, $60,1164$.

White, R. H. R., Cameron, J. S., and Trounce, J. R. (1966). British Medical fournal, 2, 853 .

Woodruff, M. F. A. (1969). Antibiotica et Chemotherapia. In press. 